\title{
WSPÓŁPRACA GMINY MIEJSKIEJ KRAKÓW I ORGANIZACJI POZARZĄDOWYCH FUNKCJONUJĄCYCH NA JEJ TERENIE - WYBRANE ASPEKTY
}

\begin{abstract}
The Selected Aspects of the Cooperation of Local Government Administration and Non-Governmental Organizations (NGO) in Cracow

The article presents information on the ways of understanding the term non-governmental organization and data on non-governmental organizations registered in the city of Krakow. The major thematic areas, undertaken by these organizations. They analyzed the forms of cooperation of NGOs and municipal authorities on the basis of prepared Multiannual Programme Cooperation Municipality of Krakow and NGOs for the years 2015-2018.
\end{abstract}

Key words: government, NGO, non-governmental organization, cooperation, Municipality of Cracow, the third sector.

\section{Streszczenie}

W artykule zaprezentowano informacje dotyczące sposobów rozumienia terminu organizacja pozarządowa oraz dane dotyczące organizacji pozarządowych zarejestrowanych na terenie miasta Krakowa. Wymieniono główne obszary tematyczne podejmowane przez te organizacje. Przeanalizowano formy współpracy NGO i organów gminy na podstawie przygotowanego Wieloletniego Programu Współpracy Gminy Miejskiej Kraków oraz Organizacji Pozarządowych na lata 2015-2018.

Słowa kluczowe: samorząd, NGO, organizacja pozarządowa, współpraca, gmina miejska Kraków, trzeci sektor. 


\section{Wstęp}

Gmina miejska Kraków w roku 2015 opracowała i uchwaliła Wieloletni Program Współpracy Gminy Miejskiej Kraków i Organizacji Pozarządowych na lata 2015-2018, w którym opisano główne elementy i plany dotyczące relacji organów gminy i przedstawicieli trzeciego sektora. Program może się przyczynić do budowania trwałych relacji, które przyczynią się do optymalnego realizowania zadań publicznych, a także rozwiązywania problemów społecznych. Realizacja postanowień programu będzie miała także pozytywny wpływ na budowanie dialogu i partycypację społeczności w podejmowaniu decyzji.

Współpraca NGO z administracją i organami władz była już w 2010 roku rekomendowana organizacjom pozarządowym działającym na terenie województwa małopolskiego przez Małopolskie Obserwatorium Polityki Społecznej w opracowaniu dotyczącym stanu trzeciego sektora w Małopolsce [Małopolskie Obserwatorium Polityki Społecznej, 2010]. Jest to kwestia istotna również z punktu widzenia rozwijającego się ruchu obywatelskiego i rosnącego zaangażowania obywateli.

Celem artykułu jest przeanalizowanie wybranych aspektów współpracy gminy miejskiej Kraków i organizacji pozarządowych działających na jej terenie oraz opisanie zaproponowanych w Wieloletnim Programie Współpracy Gminy Miejskiej Kraków z organizacjami pozarządowymi.

\section{Organizacja pozarządowa - definicja i podstawy prawne funkcjonowania organizacji pozarządowych w Polsce}

Termin „organizacja pozarządowa” często bywa stosowany zamiennie z określeniami „trzeci sektor”, „organizacje non-profit”, „organizacje społeczne” lub „NGO” (skrót od angielskiej nazwy non-governmental organisation).

Różnorodność określeń wpływa także na mnogość definicji, które można odnaleźć w literaturze. United Nation and Social Council w definicji zwraca uwagę na następujące cechy organizacji pozarządowych: utworzenie przez osoby prywatne, niezależność od organów władzy (rządu), ukierunkowanie na przestrzeganie obowiązujących przepisów prawa, posiadanie struktury organizacyjnej, możliwość działania na arenie międzynarodowej, a przede wszystkim wybieranie i realizacja celów biorących pod uwagę dobro publiczne i pomoc przy rozwiązywaniu problemów społecznych [Hobe, 1997: 191-209].

Departament Informacji ONZ proponuje, aby za organizacje pozarządowe były uważane „dobrowolne grupy obywateli, które działają w niekomercyjnym celu, a organizowane są na szczeblu lokalnym, narodowym lub międzynarodowym" [Halamska, 2008: 14].

Patrick Develtera i Benedicte Fonteneau akcentują, że organizacje pozarządowe funkcjonują poza sferą polityczną, a relacja $z$ organami władz nie ma charakteru antagonistycznego. Wiele organizacji korzysta $\mathrm{z}$ finansowego wsparcia 
rządu i możliwości, które proponuje [Halamska, 2008: 14]. Beata Filipiak i Jerzy Ruszała w swojej definicji uwzględniają wytyczne Banku Światowego, mówiąc, że organizacje pozarządowe to „organizacje prywatne, które dążą w swych działaniach do zmniejszenia cierpienia, zajmujące się promocją interesów osób biednych, ochroną środowiska naturalnego, dostarczaniem podstawowych usług socjalnych lub zajmujące się rozwojem społeczeństwa [Filipiak, Ruszała, 2009: 110].

W Polsce jednym z najważniejszych aktów prawnych dotyczącym funkcjonowania organizacji pozarządowych jest ustawa z dnia 24 kwietnia 2003 roku o działalności pożytku publicznego i o wolontariacie. Zgodnie z artykułem 3 ust. 2 Ustawy o działalności pożytku publicznego i wolontariacie za organizację pozarządową uważa się osobę prawną lub jednostkę nieposiadającą osobowości prawnej, którą utworzono na mocy przepisów oddzielnych ustaw. Wśród organizacji pozarządowych należy wymienić stowarzyszenia i fundacje. Ustawa określa, że organizacje te nie są zaliczane do sektora publicznego, a ich celem nie jest osiągnięcie zysku [Ustawa o działalności pożytku publicznego i wolontariacie, 2003, art. 3 ust. 2].

Organizacji pozarządowych nie zalicza się do sektora prywatnego, ponieważ głównym celem jej działalności nie jest osiągnięcie zysku. Nie stanowi także części sektora publicznego, ponieważ nie jest powoływana do życia przez przedstawicieli rządu i władz. NGO z podmiotami sektora prywatnego łączy charakter osoby założyciela, a więc to, że organizacja pozarządowa zakładana jest przez prywatne podmioty, społeczności, obywateli. Równocześnie omawiane organizacje stawiają sobie za zadanie realizowanie celów związanych z dobrem publicznym, pomocą w rozwiązywaniu problemów społecznych, przez co w niektórych przypadkach przyczyniają się do realizacji zadań publicznych, które to leżą w gestii podmiotów sektora publicznego.

W szerokim ujęciu wśród organizacji pozarządowych wymienić można: fundacje, stowarzyszenia i ich związki, federacje i porozumienia stowarzyszeń i fundacji, organizacje działające na mocy odrębnych przepisów (np. koła łowieckie, komitety rodzicielskie), związki zawodowe, związki pracodawców, organizacje samorządów różnych grup zawodowych (izby gospodarcze branżowe, izby rzemieślnicze i cechy z wyłączeniem izb lekarskich i Rady Adwokackiej), koła rolnicze, koła gospodyń wiejskich, organizacje kościelne, partie polityczne, a także inne typy organizacji, na przykład grupy wsparcia i kluby osiedlowe [Wygnański, 2005: 13-14]. W wąskim ujęciu są to przede wszystkim fundacje i stowarzyszenia [Wygnański, 2005: 13-14].

W literaturze przedmiotu odnaleźć można wiele funkcji, które powinny pełnić organizacje pozarządowe:

- zaspokajanie potrzeb społecznych, ze szczególnym uwzględnieniem tych, które nie mogą być zrealizowane przez państwo lub rynek;

- obniżenie kosztów związanych ze świadczeniem niektórych usług społecznych;

- przeciwdziałanie wykluczeniu społecznemu i marginalizacji poszczególnych grup lub osób;

- wspieranie inicjatyw jednostek lub grup;

- przyczynianie się do powiększania kapitału społecznego; 
- pobudzanie innowacyjności i dyskursu społecznego;

- socjalizacja obywatelska;

- wspieranie i ułatwianie przeprowadzania zmian instytucjonalnych (systemowych);

- kontrola i nadzór nad działaniami podejmowanymi przez państwo i biznes oraz reagowanie w sytuacjach nadużyć lub działań na niekorzyść poszczególnych grup interesariuszy [Hausner, 2008: 82-89].

Organizacje pozarządowe mogą pełnić wiele funkcji społecznych - przykładowo awangardy, bowiem przyczyniają się do wprowadzania nowych rozwiązań oraz inicjują zmiany. Inna ich rola jest związana z dostarczeniem dóbr i usług, których nie mogą dostarczyć państwo lub organizacje biznesowe, ale możliwe jest dostarczenie ich właśnie na drodze działalności podejmowanych przez NGO - są więc usługodawcami. Organizacje pozarządowe bywają także strażnikami wartości, gdy angażują się w ich obronę (np. podejmują działania na rzecz osób niepełnosprawnych lub osób pokrzywdzonych poprzez działania przedsiębiorstw) i promują je. Kolejna rola społeczna NGO związana jest z działaniami na rzecz grup słabo reprezentowanych w życiu społecznym lub też grup wykluczonych, można zatem określić je mianem rzeczników, gdy upominają się o ich prawa i wyrażają potrzeby [Topler, Anheier, 2006: 165].

Wspomnieć należy także znaczenie, jakie organizacje pozarządowe mają w życiu lokalnych społeczności. Przede wszystkim NGO pozostają blisko społeczności mieszkającej w danej gminie czy mieście, mogą więc szybciej reagować na pojawiające się problemy, wiedzą, komu pomoc potrzebna jest najszybciej i jak ją zorganizować. Potrafią najlepiej dopasować rozwiązanie do warunków danego miasta lub gminy. Znają mieszkańców, a mieszkańcy znają osoby związane z daną organizacją, co powoduje wzrost zaufania, a przez to także większe zaangażowanie ze strony obywateli w ich działania. NGO przyczyniają się do powstawania więzi społecznych, do budowania trwałych relacji i pozytywnych układów w społecznościach [Mepel-Śnieżyk, 2013: 93]. Ponadto podmioty trzeciego sektora przyczyniają się do budowania kapitału społecznego poprzez wspieranie współpracy między podmiotami lokalnymi [Lewenstein, 2001: 115]. Organizacje pozarządowe często powstają także jako odpowiedź na problemy występujące na danym terenie czy też jako próba przeciwdziałania nadużyciom, na przykład ze strony przedsiębiorstw czy innych organizacji. Wiele NGO to także stowarzyszenia działające na rzecz lokalnych instytucji, przykładowo stowarzyszenia prowadzące szkoły czy też działające na rzecz całych gmin lub powiatów, a także organizacje wspierające wybrane grupy zagrożone $\mathrm{z}$ różnych względów wykluczeniem, między innymi prowadzące zajęcia dla osób starszych.

Podsumowując, działalność organizacji pozarządowych jest korzystna dla lokalnych społeczności, a NGO związane z ludźmi żyjącymi na danym terenie mogą działać bardziej efektywnie i wzbudzają większe zaufanie. Przyczyniają się także do zacieśniania współpracy i wzrostu kapitału społecznego. 


\section{Organizacje pozarządowe w Krakowie - struktura i dotychczasowa współpraca z gminą miejską Kraków}

Liczba zarejestrowanych w mieście Kraków organizacji pozarządowych w lipcu 2014 roku wynosiła 3643 podmioty [Uchwała nr vi/72/15 Rady Miasta Krakowa, 2015: 2]. Natomiast w całym województwie małopolskim według stanu na grudzień 2014 roku działalność prowadziło 10433 organizacje, co stanowi 31 podmiotów na 100 tysięcy mieszkańców [Kondycja sektora organizacji pozarządowych w Polsce 2015, 2016: 28-29]. Organizacje zarejestrowane w Krakowie stanowią ok. 35\% ogółu NGO w Małopolsce.

Spośród wszystkich zarejestrowanych w mieście Kraków w lipcu 2014 roku organizacji pozarządowych 68\%, czyli 2469 podmiotów, to fundacje, 30,5\% (1117 organizacji) to stowarzyszenia, a 57 zarejestrowanych jednostek $(1,5 \%)$ to inne organizacje społeczne [Uchwała nr VI/72/15 Rady Miasta Krakowa, 2015: 2].

Organizacje pozarządowe zarejestrowane w Krakowie nie koncentrują się tylko na prowadzeniu działalności w obrębie stolicy Małopolski, ale zasięg ich działania obejmuje czasem teren województwa, a w niektórych przypadkach i teren całego kraju. Potwierdza to, fakt, że tylko 35\% zarejestrowanych w Krakowie organizacji pozarządowych funkcjonuje i realizuje projekty tylko na terenie gminy lub powiatu. Działające w Krakowie NGO zajmują się głównie projektami związanymi z kulturą, edukacją, sportem i rekreacją, działalnością charytatywną i pomocą społeczną. Najmniej przedstawicieli trzeciego sektora podejmuje tematy, takie jak prawo czy rozwój gospodarczy [Uchwała nr VI/72/15 Rady Miasta Krakowa, 2015: 2]. NGO w skali całej Polski jako tematykę działań najczęściej wybierają następujące dziedziny: sport, turystyka, rekreacja i hobby (34\%), edukacja i wychowanie (15\%), kultura i sztuka (13\%), ochrona zdrowia (8\%), usługi socjalne i pomoc społeczna (7\%), rozwój lokalny (6\%) [Adamiak, Charycka, Gumkowska, 2016: 31-32].

W 2014 roku przeprowadzono badania na zlecenie gminy miejskiej Kraków oraz Fundacji Biuro Inicjatyw Społecznych, które miały dostarczyć informacji o funkcjonowaniu trzeciego sektora na terenie Krakowa. Uzyskane dane miały pomóc w opracowaniu planu współpracy gminy miejskiej Kraków i NGO. Jak wynika $\mathrm{z}$ badania, połowa respondentów współpracuje lub współpracowała z gminą miejską Kraków. Współpracę tę pozytywnie ocenia $40 \%$ badanych organizacji. Warto podkreślić, że głównym powodem podejmowania współpracy, deklarowanym przez badane organizacje, była możliwość uzyskania pomocy finansowej [Uchwała nr VI/72/15 Rady Miasta Krakowa, 2015: 3]. Powód ten jest zrozumiały, ponieważ organizacje działające $\mathrm{w}$ trzecim sektorze nie zawsze mają stałe źródło finansowania. Ich działalność często ogranicza się do realizacji projektów w ramach różnorodnych grantów. Finansowanie jest ważne także, ponieważ umożliwia wypłatę stałych wynagrodzeń i utrzymanie kadry. Warto podkreślić, że organizacje pozarządowe cechuje duża rotacja pracowników spowodowana również kwestiami finansowymi i trudnością w konkurowaniu o pracowników, zwłaszcza specjalistów. Kwestie związane z dużą rotacją pracowników, brakiem 
profesjonalnej kadry i brakiem stałego źródła finansowania były wymieniane jako słabe strony małopolskich organizacji pozarządowych już w 2010 roku w przygotowanym przez Małopolskie Obserwatorium Polityki Społecznej opracowaniu dotyczącym stanu trzeciego sektora w Małopolsce i rekomendacji dla organizacji pozarządowych na dalsze lata działalności [Małopolskie Obserwatorium Polityki Społecznej, 2010]. Należy zatem zaznaczyć, że wsparcie finansowe udzielane przez gminę miejską Kraków w postaci grantów oraz zlecanie wybranym organizacjom pozarządowym realizacji zadań publicznych jest korzystne. Nie można jednak współpracy NGO z przedstawicielami samorządu ograniczyć tylko do tej formy.

Dziedziny, w ramach których współpraca pomiędzy gminą miejską Kraków i organizacjami pozarządowymi pokrywa się z głównymi obszarami działalności krakowskich NGO, to kultura, sport i rekreacja. Najrzadziej podejmowane są projekty i współpraca z zakresu rozwoju gospodarczego. Badane organizacje wskazywały również takie obszary, jak: rozwój społeczeństwa obywatelskiego, zagospodarowanie przestrzenne $\mathrm{i}$ architektura oraz promocja miasta [Uchwała $\mathrm{nr}$ VI/72/15 Rady Miasta Krakowa, 2015: 3].

$\mathrm{Z}$ omawianego badania wynika, że najczęściej organizacje pozarządowe zawiązują współprace z organami administracji na dłużej niż jeden rok, stosunkowo rzadko jest to współpraca jednorazowa lub trwa krócej niż jeden rok. Najczęściej kooperacja przybiera formę udziału w konkursach ofert, jest to więc w przeważającej części wsparcie finansowe [Uchwała nr VI/72/15 Rady Miasta Krakowa, 2015: 4].

\section{Wieloletni Program Współpracy Gminy Miejskiej Kraków z Organizacjami Pozarządowymi na lata 2015-2018 - założenia, przyjęte formy współpracy i już zrealizowane elementy}

28 stycznia 2015 roku Rada Gminy Miejskiej Kraków przyjęła uchwałę, zgodnie z którą wprowadzony został Wieloletni Program Współpracy Gminy Miejskiej Kraków z Organizacjami Pozarządowymi na Lata 2015-2018. Głównymi celami programu są „rozwój dialogu społecznego pomiędzy organizacjami pozarządowymi a gminą, wzrost zaangażowania organizacji pozarządowych i poprawa efektywności realizacji zadań publicznych, rozwój sektora pozarządowego w Krakowie oraz poprawa jakości i innowacyjności działania" [Uchwała nr VI/72/15 Rady Miasta Krakowa, 2015: 8].

Program prezentuje także zasady, na jakich ma się opierać współpraca, a także omawia jej formy, akcentując przede wszystkim sposoby współpracy pozafinansowej. Wynika to głównie z potrzeby włączenia organizacji pozarządowych w proces dialogu i realizacji zadań publicznych. Partycypacja organizacji pozarządowych jest niezwykle istotna, ponieważ niejednokrotnie znają one lepiej potrzeby obywateli (gdyż to właśnie oni często je tworzą), są bliżej społeczności, znają i rozumieją więc lepiej jej problemy. Organizacje pozarządowe specjalizują 
się zwykle w jednym lub kilku pokrewnych obszarach, co może pomóc im odgrywać rolę eksperta, a także zapewnia dostęp do aktualnych informacji. Organizacje pozarządowe cieszą się zazwyczaj zaufaniem obywateli, co również może mieć pozytywny wpływ na realizację danego zadania. Dzięki współpracy organów samorządu terytorialnego i NGO możliwa jest wymiana wiedzy, dyskusja, a przez to znalezienie rozwiązań, które zarówno będą optymalne ze względu na koszty, jak i będą brały pod uwagę inne istotne czynniki, a szczególnie te najważniejsze dla obywateli.

Zasady współpracy opisane w Wieloletnim Programie..., wraz z krótką charakterystyką, przedstawia tabela 1 . Warto zauważyć, że opracowanie zasad i szczegółowe ich wypisanie w programie przyczynia się do usystematyzowania współpracy, wyznacza standardy, a także pokazuje, jak w swojej działalności muszą postępować partnerzy, aby współpraca była jak najbardziej efektywna i zadawalająca, nie tylko dla obu stron, ale i dla beneficjentów zewnętrznych, na przykład grup zagrożonych wykluczeniem.

Tabela 1

Zasady współpracy gminy miejskiej Kraków z organizacjami pozarządowymi

\begin{tabular}{|l|l|}
\hline Zasada & Opis \\
\hline subsydiarności & $\begin{array}{l}\text { naturalne prawo społeczności lokalnej do samo- } \\
\text { decydowania oraz samodzielnej realizacji zadań } \\
\text { uznanych przez nią za istotne; }\end{array}$ \\
\hline suwerenności stron & $\begin{array}{l}\text { niezbywalne prawo mieszkańców do niezależno- } \\
\text { ści względem władzy publicznej; }\end{array}$ \\
\hline partnerstwa stron & $\begin{array}{l}\text { fundament współpracy równych i niezależnych } \\
\text { podmiotów w zakresie definiowania problemów } \\
\text { społeczności lokalnej oraz poszukiwania najlep- } \\
\text { szych modeli ich rozwiązania; }\end{array}$ \\
\hline efektywności & $\begin{array}{l}\text { dążenie do maksymalizacji korzyści mieszkań- } \\
\text { ców z realizowanych wspólnie zadań publicz- } \\
\text { nych; }\end{array}$ \\
\hline uczciwej konkurencji & $\begin{array}{l}\text { stosowanie we współpracy jednakowych i trans- } \\
\text { parentnych zasad; }\end{array}$ \\
\hline jawności & $\begin{array}{l}\text { nieustanne dążenie do zwiększenia przejrzysto- } \\
\text { ści wszelkich działań; }\end{array}$ \\
\hline współodpowiedzialności & $\begin{array}{l}\text { wspólne dążenie do polepszania życia mieszkań- } \\
\text { ców poprzez odpowiedzialność względem part- } \\
\text { nerów za działania podejmowane przez sektor } \\
\text { pozarządowy i administrację samorządową. }\end{array}$ \\
\hline
\end{tabular}

Źródło: Wieloletni Program Współpracy Gminy Miejskiej Kraków z organizacjami pozarządowymi na lata 2013-2018, Uchwała Nr VI/72/15 Rady Miasta Krakowa z 28 stycznia 2015: 7. 
Wieloletni Program... proponuje wiele różnych możliwości współpracy:

- informowanie o kierunkach planowanych działań;

- konsultacje aktów prawa dotyczących NGO oraz planów współpracy z NGO;

- tworzenie wspólnych zespołów doradczych;

- działania Krakowskiej Rady Pożytku Publicznego;

- działanie Komisji Dialogu Obywatelskiego;

- prowadzenie miejskiego portalu informacyjnego dla organizacji pozarządowych;

- działanie Dzielnicowych Centrów Organizacji Pozarządowych;

- pomoc w nawiązywaniu partnerstw regionalnych i udzielanie rekomendacji;

- promowanie pozytywnego wizerunku NGO [Uchwała nr VI/72/15 Rady Miasta Krakowa, 2015: 12].

Działania zaproponowane w omawianym programie wieloletnim zarówno dotyczą czynności związanych z przekazywaniem informacji o podejmowanych działaniach, jak i wprowadzają nowe organy doradcze, takie jak Krakowską Radę Pożytku Publicznego czy też Komisje Dialogu Obywatelskiego. Niezwykle ważnym elementem jest także promowanie pozytywnego wizerunku NGO, co pozwala budować zaufanie do NGO, a rekomendacje mogą pomóc podmiotom trzeciego sektora w kontaktach z biznesem, a także pozyskiwaniu partnerstw i finansowania od innych podmiotów, między innymi organów władzy na szczeblu krajowym.

Wprowadzenie organów doradczych, w postaci Komisji Dialogu Obywatelskiego, pozwoli na bieżąco konsultować projekty czy też pomysły na realizację określonych zadań publicznych. Bardzo ważne jest także konsultowanie katów prawnych dotyczących organizacji pozarządowych z nimi samymi, co pozwoli na jak najlepsze dopasowanie rozwiązań do warunków w jakich funkcjonują NGO, a także umożliwi już na początku prac nad danym wprowadzenie ewentualnych zmian, czy też wyjaśnienie wątpliwości.

Omawiany plan wieloletniej współpracy uchwalony został rok temu. Obecnie realizowanych jest kilka projektów, które mają być przejawem wypełniania przyjętych propozycji. Przykładem może być uruchomienie portalu internetowego pod adresem ngo.krakow.pl, na którym znajdują się informacje przydatne dla organizacji pozarządowych. Poza aktualnościami i wydarzeniami przedstawiciele trzeciego sektora mogą znaleźć na portalu informacje o dotacjach, podstawowe porady prawne dotyczące kwestii formalnego funkcjonowania organizacji, a także odnośniki do przydatnych i wartościowych instytucji.

Drugim istotnym projektem było utworzenie Centrum Obywatelskiego w Krakowie, instytucji, która ma siedzibę w budynku Stadionu Miejskiego im. H. Reymana przy ulicy Reymonta w Krakowie. Centrum Obywatelskie ma tworzyć przestrzeń do dialogu społecznego, ma za zadanie także świadczyć ofertę inkubacji organizacji pozarządowych, udostępniając im między innymi przestrzeń biurową. Centrum Obywatelskie posiada bogatą ofertę szkoleniową dla przedstawicieli trzeciego sektora, organizuje szkolenia z komunikacji i zarządzania projektami. Centrum Obywatelskie udostępnia także publikację i bazę wiedzy oraz organizuje 
wydarzenia, w czasie których możliwa jest wymiana kontaktów i nawiązywanie nowej współpracy, a także pozwala na omówienie swoich pomysłów. Jest to dobra okazja do wymiany wiedzy i konfrontacji projektu z opiniami innych, co umożliwia uzyskanie świeżego spojrzenia na projekt i dostrzeżenie ewentualnych błędów.

W ciągu roku od uchwalenia planu współpracy funkcjonowanie rozpoczęły także Komisje Dialogu Obywatelskiego. Utworzono następujące Komisje Dialogu Obywatelskiego:

- Komisja Dialogu Obywatelskiego ds. Rewitalizacji Nowej Huty;

- Komisja Dialogu Obywatelskiego ds. Środowiska;

- Komisja Dialogu Obywatelskiego ds. Zdrowia;

- Komisja Dialogu Obywatelskiego ds. Bezpieczeństwa;

- Komisja Dialogu Obywatelskiego ds. Osób Niepełnosprawnych.

Wyodrębnienie kilku komisji pozwala na lepsze dopasowanie organizacji do tematyki, a także zmniejsza obciążenie pracą. Gdyby istniała tylko jedna komisja, musiałaby ona analizować większa liczbę projektów. Utworzenie pięciu Komisji Dialogu Obywatelskiego i przyporząakowanie im obszarów tematycznych pozwala skierować projekt do odpowiedniego organu doradczego, w którym zasiadają kompetentne organizacje, posiadające wiedzę zarówno o potrzebach obywateli, jak i o trendach i sposobach rozwiązywania danego problemu.

Wymienione przykłady to tylko kilka wybranych form współpracy gminy i NGO. W programie współpracy wieloletniej znalazł się cały wachlarz form współpracy - ta różnorodność pozwala na zaangażowanie dużej liczby organizacji, a dzięki temu uzyskanie różnych punktów widzenia i uwag. Plan wprowadzony został na trzy lata.

\section{Podsumowanie}

Coraz większa liczba obywateli aktywnie angażuje się w sprawy społeczne. Bardzo ważnym elementem tego zaangażowania jest członkostwo w organizacjach pozarządowych, a także sama działalność tych organizacji, które z jednej strony nadzorują działania administracji i władz, a $\mathrm{z}$ drugiej mogą pomóc $\mathrm{w}$ realizacji zadań publicznych. NGO, które często dysponują szeroką wiedzą na temat społeczności oraz tematu, w którym się specjalizują, mogą być dobrymi organami doradczymi, które przyczynią się do tworzenia optymalnych rozwiązań. Współpraca $z$ organami władz jest także korzystna dla NGO, ponieważ pozwala na zdobycie rekomendacji i zaufania, a dzięki temu umożliwia współpracę z nowymi podmiotami, powoduje także wzrost profesjonalizmu organizacji pozarządowej.

Współpraca organizacji pozarządowych działających na terenie gminy miejskiej Kraków może odbywać się na podstawie Wieloletniego Programu Współpracy... uchwalonego przez Radę Miasta. Aby tak się stało, zarówno NGO, jak i przedstawiciele władz powinni aktywnie działać na rzecz promocji swojej działalności, komunikować swoje projekty w sposób przejrzysty i stosować się do zasad 
współpracy, które zostały wyszczególnione w programie. Przedstawiciele władz powinni korzystać z doświadczenia pracowników organizacji pozarządowych, którzy często posiadają najbardziej aktualną wiedzę o problemach mieszkańców, z ich pomocy i doradztwa przy wprowadzaniu kolejnych rozwiązań, na przykład komunikacyjnych, oraz przy ich współpracy przeprowadzać konsultacje społeczne. Szczególnie zaś powinny zwracać uwagę na opinie NGO, które powstają z oddolnej inicjatywy mieszkańców, na przykład jako efekt ich niezadowolenia z sytuacji. Ich powstanie może świadczyć o tym, że mieszkańcy mają jakiś problem, na który władze nie zwróciły uwagi lub który został przez nie zbagatelizowany.

Podsumowując, opracowany w Krakowie program współpracy jest pozytywną inicjatywą, która może pomóc usystematyzować relacje z NGO, a także przyczynić się do spopularyzowania innych form współpracy, a nie tylko wsparcia finansowego w postaci grantów. Równocześnie jednak odpowiedni poziom wsparcia finansowego może zapewnić organizacji stabilność i możliwość budowania trwałego zespołu pracowników.

\section{Bibliografia}

Adamiak P., Charycka B., Gumkowska M. (2016), Kondycja sektora organizacji pozarzadowych $w$ Polsce 2015. Raport z badań, Stowarzyszenie Klon/Jawor, Warszawa.

Filipiak B., Ruszała J. (2009), Instytucje otoczenia biznesu. Rozwój, wsparcie, instrumenty, Wydawnictwo Difin, Warszawa.

Halamska M. (2008), Wiejskie organizacje pozarzadowe. Wprowadzenie [w:] M. Halamska, Wiejskie organizacje pozarzadowe, Instytut Rozwoju Wsi i Rolnictwa Polskiej Akademii Nauk, Warszawa.

Hausner J. (2008), Zarzadzanie publiczne, Wydawnictwo Naukowe Scholar, Warszawa.

Hobe S. (1997), Golobal Challanges to Statehood: The Increasingly Important Role of Nongovernmental Organisations, „Indiana Journal of Global Legal Studies”, 1(5).

Kurleto M.H. (2008), Organizacje pozarządowe $w$ działalności pożytku publicznego, Lexis Nexis, Warszawa.

Lewenstein B. (2001), Obywatelskie strategie i modele wprowadzania „zmiany społecznej” w miejskich spolecznościach lokalnych - doświadczenia amerykańskie [w:] Aktywność obywatelska w rozwoju społeczności lokalnej, red. M. Wadowicki, Z. Woźniak, Wydawnictwo Municipium, Warszawa.

Małopolskie Obserwatorium Polityki Społecznej (2010), Potencjał Małopolskich Organizacji Pozarzadowych, Regionalny Ośrodek Polityki Społecznej w Krakowie, Kraków.

Mepel-Śnieżyk A. (2013), Organizacje pozarządowe i społeczności lokalne, a skuteczne działanie dla rozwoju lokalnego [w:] Acta Universitatis Lodziensis. Folia Oeconomica, nr 289, Łódź.

Topler S., Anheier H.K. (2006), Zarys ogólny teorii organizacji i zarzadzania organizacjami non profit [w:] Trzeci sektor dla zaawansowanych. Wspótczesne teorie trzeciego sektora-wybór tekstów, opracowanie: Wygnański J.J., Gałązka A., Herbst J., Stowarzyszenie Klon/Jawor, Warszawa. 
Uchwała Nr VI/72/15 Rady Miasta Krakowa z 28 stycznia 2015, dotyczy Wieloletniego Programu Współpracy Gminy Miejskiej Kraków z organizacjami pozarządowymi na lata 2013-2018.

Ustawa z dnia 24 kwietnia 2003 r. o działalności pożytku publicznego i o wolontariacie, Dz.U. $2003 \mathrm{nr} 96$ poz. 873 z późniejszymi zmianami.

Wygnański J. (2005), Terminologia [w:] Stowarzyszenie Klon/Jawor (2005), Elementarz III sektora, Warszawa. 